\title{
Kreftregisteret - fra registrering av kreftinsidens og overlevelse til populasjonsbasert klinisk epidemiologi
}

\author{
Frøydis Langmark og Jarle Norstein \\ Kreftregisteret, Montebello, 0310 Oslo \\ Korrespondanse: Frøydis Langmark, Kreftregisteret, Montebello, 0310 Oslo \\ Telefon $22451300 \quad$ Telefax $22451370 \quad$ E-post: fl@kreftregisteret.no
}

\begin{abstract}
SAMMENDRAG
Kreftregisteret har siden sin opprettelse for 50 år siden hatt som hovedoppgave å registrere nyoppdagede krefttilfeller etter organlokalisasjon, svulsttype, svulstutbredelse og en del andre medisinske forhold. De registrerte opplysningene har vært fullstendige og gode på grunn av et godt rapporteringssystem med tre uavhengige kilder: patologiavdelinger, kliniske avdelinger og Dødsårsaksregisteret. Populasjonsbaserte data har dannet grunnlaget for forskning på årsaker og risikofaktorer for å få kreft, med vekt på forebygging av kreft. Kreftbildet i Norge har endret seg fra 50-årene hvor flertallet av kreftpasientene døde av sin sykdom, til i dag hvor over halvparten av de over 22000 pasienter som diagnostiseres årlig vil overleve. Det lever i dag ca. 155000 pasienter som har eller har hatt kreft. Den økende betydningen av behandling og kreftpasientenes bedrede leveutsikter har påvirket Kreftregisterets arbeid. Det fremstår som stadig viktigere å ha en korrekt registrering av ikke bare karakteristika ved svulsten, men også forhold rundt diagnostikk og behandling. I løpet av de siste 15 år har Kreftregisteret utvidet sitt virkefelt til å omfatte screening og registrering av populasjonsbaserte data om behandling og tilbakefall av kreft etter behandling. Forholdene ligger særlig godt til rette for populasjonsbasert klinisk forskning i Norge på grunn av vårt fødselsnummersystem som gir mulighet for god oppfølging av behandlingsresultater. Kreftregisteret vil være et kvalitetsregister for alle svulstformer og vi vil i tiden fremover legge vekt på utvidet og landsomfattende samarbeid med fagmiljøer som innehar ekspertise på de enkelte svulstformer for å bedre vår registrering og legge forholdene til rette for aktivitet som kan gi bedre resultater både av behandling og forskning.
\end{abstract}

\section{Langmark F, Norstein J. The Cancer Registry of Norway - from registration of cancer incidence and survival to population-based clinical epidemiology. Nor J Epidemiol 2004; 14 (1): 39-46.}

\section{ENGLISH SUMMARY}

The Cancer Registry of Norway has since it was established 50 years ago had its main objective in registration of newly diagnosed cases of cancer by location, tumour type, stage and other medical conditions. The data quality has been high due to independent reporting from 3 sources: departments of pathology, clinical departments, and the Cause of Death Registry of Statistics Norway. Population based data have been utilised for research on causes of cancer and risk factors for developing cancer. The cancer situation has changed since the 1950-ies when the majority of cancer patients died of their disease till today when more than 50 percent survive. At present, 155,000 patients who have or have had cancer are alive in Norway. The increased significance of treatment and the improved survival prospects for patients have influenced the priorities of the Cancer Registry. It is increasingly important to obtain a correct registration, not only of characteristics of the tumour, but also of results of clinical investigations and of treatment. During the past 15 years the Cancer Registry has expanded to include screening and recording of population based data on treatment and recurrence after treatment. The conditions for population based clinical research are favourable in Norway due to a unique identity number for every citizen, ensuring complete follow-up. The Cancer Registry of Norway has an ambition to be a high quality registry for all tumour types. We will in the future increase our efforts to establish a nation-wide co-operation with specialists within the various tumour fields in order to improve our registration and provide a data base for improved treatment and high quality research.

\section{INNLEDNING MED HISTORIKK}

Forskningen i tradisjonelle kreftregistermiljøer er sentrert om årsaks- og risikoforskning. Denne forskningen har fortsatt en stor plass i Kreftregisteret, i sær relatert til risikofaktorer for kreft innen forskjellige yrkesgrup- per, i det ytre miljø generelt som radioaktiv stråling, elektromagnetisk felt, ultrafiolett lys samt endogene faktorer relatert til kosthold, hormoner og annet (1-8). Hermed genereres kunnskap også til bruk for helsemyndigheter og forebyggingsinstitusjoner. Kreftregisteret har de siste 15 år utvidet sitt virkefelt betydelig $\mathrm{i}$ 
forhold til dette, og det er disse nye arenaene: screening og klinisk forsknings registerpremisser som omhandles i denne artikkelen. Det er imidlertid viktig å påpeke at selv om Kreftregisteret er opptatt av å utføre den samfunnsnyttige dokumentasjonsforskningen vedrørende såvel årsakene til kreft som helsetjenestene involvert i diagnostikk og behandling, vet vi at vi har et unikt utgangspunkt for original grunnforskning uten umiddelbar nytteverdi. Et viktig strategisk spørsmål er hvordan skape rom og ressurser for akkurat denne forskningen. Den begrensede, til dels manglende kunnskap om viktige aspekter ved sykdomsregistrering og uttrekk av biobanker i såvel medisinske som politiske miljøer er også et tema for Kreftregisterets strategiske tanker. En felles og helt sentral oppfatning i vårt og andre kreftregistermiljøer er at forskerne får bedre kompetanse og mulighet for å produsere forskningsarbeid av høyere kvalitet ved å være tett knyttet opp mot kvalitetssikringen av registerdatabasen.

I Norge har Kreftregisteret siden sin opprettelse i 1951 hatt som hovedoppgave å registrere nyoppdagede krefttilfeller etter organlokalisasjon, svulsttype, svulstutbredelse og en del andre medisinske forhold. Det har fra starten vært tre uavhengige kilder til opplysningene. Den viktigste kilden har vært meldinger fra avdelinger for patologi om alle ondartede vevs- og cellediagnoser. Meldingene har etter hvert tatt form av kopier av patologiremissene, arbeidsdokumentet som er kommunikasjonsleddet mellom klinikerne (leger som behandler pasienter i og utenfor sykehus) og patologene. I de siste år har også melding blitt sendt som datautskrifter på papir. I tillegg har klinikerne selvstendig meldeplikt om alle krefttilfeller de diagnostiserer, uansett om det foreligger patologisk-anatomisk verifikasjon eller ei. Endelig har Kreftregisteret fått melding om alle dødsattester innsendt til Dødsårsaksregisteret og hvor kreft nevnes. I utgangspunktet var dette meldesystemet konstruert slik at ingen kreftpasient skulle kunne unngå å bli registrert, bl.a. fordi man for nesten alle pasienter skulle få melding fra minst to uavhengige kilder. Registreringen i Kreftregisteret har vært gjennomført med stor nøyaktighet, og har dannet grunnlaget for mange vitenskapelige undersøkelser om utviklingen i kreftbildet og om risikofaktorer for å få kreft, den etiologiske kreftforskningen (8).

Mens et flertall av kreftpasientene på femtitallet døde av sin sykdom, vil i dag halvparten av de over 22000 nordmenn som årlig får kreft, være i live mer enn 5 år etter at diagnosen ble stilt (9). Tradisjonelt har 5-års overlevelse vært betraktet som tegn på at pasienten er helbredet for kreftsykdommen. Det lever i Norge i dag ca. 155000 pasienter som en gang har fått en kreftdiagnose (9). Forklaringene på de bedrede leveutsiktene er mange: bedre allmenntilstand og økt kunnskap hos befolkningen og bedrede helsetjenester $\mathrm{i}$ alle ledd. Tidligere diagnose av kreftsvulsten medfører bl.a. at flere av kreftpasientene kan få helbredende, og ofte mindre omfattende behandling. I takt med denne utviklingen har Kreftregisteret utvidet sine aktiviteter fra først og fremst å bidra til å oppnå ny kunnskap om hva som leder til kreft, til også å bidra til kunnskapsøkningen om hvordan overlevelsesmulighetene kan forbedres. Registrering av mer detaljerte sykdomsutrednings- og behandlingsdata på det primære diagnosetidspunktet såvel som ved progresjon av sykdommen, har tvunget seg frem. Et av mange viktige forhold er at til tross for at primærbehandlingen $\mathrm{i}$ mange tilfeller antas helbredende, får en stor andel også av disse kreftpasientene tilbakefall av sykdommen. Hvorfor det er slik vet vi ikke nok om. Og det finnes intet godt nok pasientmateriale til i dag å gi svar. Heller ikke har vi oversikt over hvilke pasienter som får ny kurativ behandling ved tilbakefall eller hvilke man kun tilbyr dødsutsettende behandling. $\AA$ vekte livskvalitet mot livskvantitet er også et område der vi vet for lite. I noen tilfeller kan tilbakefall behandles med begrunnet håp om helbredelse, særlig hvis tilbakefallet oppdages tidlig. Men mange tilbakefall kan kun behandles med dødsutsettende og/eller lindrende behandling. Valget av plagsomme og dyre cellegiftbehandlinger som utsetter døden noen få uker eller måneder kan være vanskelig å ta både for behandler og pasient. Ressursinnsatsen totalt ved behandling av tilbakefall er meget stor, og resultatene $\mathrm{i}$ form av varig helbredelse antakelig beskjedne. Vi har imidlertid ingen pålitelig statistikk over "lønnsomheten" av denne type kreftbehandling. Det er videre viktig å være klar over at for en del svulstformer kan typen av tilbakefall gi viktig informasjon om kvaliteten av den opprinnelige behandlingen. Vi har således mange gode grunner for å gripe fatt i denne upløyde mark, nettopp i Kreftregisterets tverrfaglige forskningsmiljø og med den relevante registerkompetansen.

\section{STATUS I DAG}

Kreftregisteret har i dag gode data om nydiagnostiserte kreftpasienters svulstutbredelse på diagnosetidspunktet. Det har imidlertid manglet data om pasientenes symptomer, andel av pasientene som har fått stilt kreftdiagnosen på bakgrunn av systematisk eller usystematisk screening, og om forsinkelser i diagnostikk og behandling (patient's delay og doctor's delay). Dette er opplysninger som fra 1.1.2003 er tatt inn som meldepliktige i reviderte skjemaer for kreftmelding. Det foreligger fra tidligere år en del data om typen av behandling som gis, men opplysningene har ikke vært detaljerte og ikke fullt ut komplette.

En stor bekymring for Kreftregisteret har vært at bare ca. 35\% av krefttilfellene er blitt meldt spontant av klinikerne. Det betyr at systemet med uavhengig rapportering fra flere kilder ikke har fungert tilfredsstillende. Etter purring på kliniske opplysninger, som sendes ut med basis i meldinger fra patologiavdelingene, har Kreftregisteret fått inn kliniske meldinger med opplysninger om sykdomsutbredelse i ytterligere $35 \%$ av tilfellene. Kreftregisteret har ved denne inkompletthet og forsinkelse tapt viktige data om 
sykdomsutbredelse ved behandlingsstart. Dette er noe av bakgrunnen for at Kreftregisterforskriften (www.lovdata.no), som trådte i kraft fra 1.1.2002, har fastsatt at institusjonene som diagnostiserer og behandler kreftpasienter skal ha en plikt til å ha systemer som sikrer at melding om kreft blir sendt innen 2 måneder etter at opplysninger om kreft er dokumentert. Tidligere var det den enkelte lege som hadde meldeplikten, og det var ingen tidsfrist. Kreftregisterforskriften har medført et sceneskifte i kreftmeldesituasjonen, slik at det ved de fleste helseinstitusjoner som behandler kreftpasienter nå er etablert meget gode systemer for kreftmelding. Krefregisteret har også hatt god hjelp i at vi fra 1998 har fått elektronisk overførte pasientadministrative data fra landets sykehus med opplysninger om alle innleggelser og storparten av de polikliniske konsultasjonene for kreftsykdom. Komplettheten i rapporteringen til Kreftregisteret for solide svulster har vært 98-99\% (10,11). Med hjelp til identifikasjon av pasienter fra pasientadministrative data er komplettheten i ferd med å nærme seg $100 \%$, og rapporteringen av kliniske opplysninger for pasienter identifisert på denne måten er nå over $96 \%$ og økende.

Likesom i andre land har obduksjonshyppigheten falt i Norge. Forklaringen på fallende obduksjonshyppighet er hovedsakelig manglende kapasitet ved avdelingene for patologi på grunn av den økende arbeidsbelastning vedrørende blant annet økt kreftdiagnostikk på pasienter som er i live. Kreftregisteret taper derved en viktig kilde (obduksjonsrapportene fra patologene) til kunnskap om sykdomsutbredelse ved dødstidspunktet og kvalitetssikring av opplysninger om dødsårsak. I tillegg tapes annen informasjon som obduksjon kan gi svar på, så som organskader pga. behandlingen.

Et annet forhold som ville bidra til å sikre datakvaliteten, er resultatene av billeddiagnostiske undersøkelser. De opprinnelige 50 år gamle statuttene for Kreftregisteret påbød slik rapportering. Spesielt i forhold til diagnosen av sykdomsutbredelse (stadium) er billeddiagnostikken ofte eneste diagnosegrunnlag, når det ikke foreligger patologisk verifikasjon.

Data om tilbakefall er i dag meget ufullstendige i Kreftregisteret, spesielt fordi når det gjelder dokumentasjon av tilbakefall og progresjon av sykdommen, utgjør billeddiagnostikk alene en betydelig andel.

Manglende opplysninger om forhold ved såvel primærdiagnostikk og -behandling som ved kreftpasientenes situasjon ved progresjon av sykdom, har store konsekvenser for planlegging og anvendelse av ressurser i kreftomsorgen. Det foreligger i dag ikke tilfredsstillende underlag for beslutninger om hvilke ressurser som bør settes inn mot primærdiagnostikk og -behandling, og atskillig dårligere underlag når det gjelder tilbakefall av kreft. En stor innsats for å bedre dette feltet har vært ytet av de frivillige gruppene av spesialister innen kreftomsorgen så som Norsk Bryst Cancer Gruppe, Norsk Gastro Intestinal Cancer Gruppe og andre faggrupper under Onkologisk Forum som igjen er støttet av Den Norske Kreftforening. Men det er langt igjen.

I lys av dette blir kostnader og effekt ved screening av kreft vanskeligere å evaluere opp mot de heterogene diagnostiske og terapeutiske innsatsene rettet mot de ordinære pasientene som ikke er oppdaget ved systematisk masseundersøkelse, som i dag bare omfatter livmorhalskreft og brystkreft. Screeningprogrammene har i tillegg til gevinsten ved tidlig oppdagelse av kreft eller forstadier til kreft også bidratt til å bedre behandlingen ved standardisering av behandlingstilbudet, som også har hatt virkninger ut over de pasienter som har vært omfattet av screeningprogrammene. Også forebyggingstiltak utenom masseundersøkelser burde selvsagt taes inn i kreftomsorgens totalregnestykke. Her vil vi imidlertid konsentrere oss om Kreftregisterets oppgaver i relasjon til primær- og sekundærsituasjonen for allerede etablerte kreftpasienter.

I det følgende redegjøres det for mulige strategier for å innhente et bedre beslutningsgrunnlag på en kostnadseffektiv måte, og hvor man utnytter de særskilte fortrinn norsk helsevesen har i forhold til andre land. Det er grunn til å tro at en kunnskapsbasert kvalitetssikring av kreftomsorgen vil gi vesentlig bedret overlevelse og bedret livskvalitet for kreftpasientene og det med en forholdsvis begrenset tilførsel av nye ressurser. De erfaringer man her høster kan dessuten få gunstig overføringsverdi for totalsatsingen overfor andre alvorlige, kroniske sykdommer i Norge. Et bedret datagrunnlag gir også et bedre materiale for epidemiologisk og klinisk forskning.

\section{KREFTREGISTERETS FREMTIDIGE BIDRAG MOT SYKELIGHET OG DØDELIGHET AV KREFT}

Screening for å oppdage forstadier til kreft før kreft har utviklet seg er $\mathrm{i}$ dag et alternativ som kun er mulig for noen få kreftformer, i hovedsak for livmorhalskreft, tykktarmskreft og endetarmskreft. Tidligdiagnostikk av allerede utviklet kreft ved screening, før den har gitt symptomer, er i dag teknisk/klinisk mulig for kreft i hud, munnhule, svelg, spiserør, magesekk, tolvfingertarm, lever, tykktarm, endetarm, lunger, bryst, livmorhals, livmor, prostata og urinblære. Screening er forøvrig også aktuelt for enkelte høyrisikogrupper, basert på arvelig disposisjon eller hvor det foreligger høy eksponering for kjente kreftfremkallende agens. Behandlingen ved tidligdiagnostikk vil oftest være enklere enn om kreftsykdommen hadde vært oppdaget $\mathrm{i}$ et senere stadium. Det er grunn til å tro at helbredelsesprosenten vil øke atskillig, selv om nok den kommende forskning på det menneskelige genoms funksjoner vil bidra til at vi bedre vil forstå hvorfor meget tidlig diagnose ikke alltid er tidlig nok. Uansett er det klart at screening for å oppdage forstadier til eller utviklet kreft krever nøyaktig den infrastrukturen og tverrfaglige spesialistkompetanse som Kreftregisteret har. Derfor har det for Kreftregisteret vært viktig å 
vinne forståelse for at $\mathrm{i}$ en befolkning på 4,5 millioner mennesker, ville opprettelse av eksterntliggende registre for kreftscreening på sikt bli fordyrende, samtidig som man ville spre hardt ervervet spesialkompetanse tynt utover. Selv om kreft er en hyppig sykdoms- og dødsårsak totalt, har den enkelte kreftform sin særegne problematikk. Det er derfor viktig å konsentrere denne kompetansen og skape et rikt miljø med attraktivt mangfold i forskningen omkring de forskjellige kreftformers biologi og naturlige utvikling.

Screening har imidlertid et begrenset omfang i dag. Det er primærbehandlingens art og kvalitet rettet mot kreft, uansett hvorledes sykdommen er oppdaget, som er av avgjørende betydning for utfallet for de fleste kreftformene. Svulstens natur og utbredelse ved diagnosetidspunktet er også av stor betydning. Om tilbakefall og progresjon av sykdom skyldes svulstens natur, primærutbredelsen eller svikt i primærbehandlingen kan være vanskelig å si noe sikkert om, men erfaring har vist at $\mathrm{i}$ noen tilfeller kan systemsvikt såvel som individfeil på behandlernivå korrigeres med minimale utlegg, slik vi har sett eksempler på ved endring av kirurgisk behandlingsmetode for endetarmskreft (12). Dette vil systematisert kunne gi store kostnadsbesparelser ved at man slipper utgifter til behandling av tilbakefall og langtkommen kreft, i tillegg til den menneskelige lidelse, nød og død man derved forebygger.

Optimalisert primærbehandling er dermed det tiltak som kan gi størst effekt $\mathrm{i}$ forhold til ressursinnsatsen på kort og også på temmelig lang sikt. Gevinsten ved optimalisert primærbehandling bør derfor tas ut i fullt monn. En nøkkel til påvisning av svikt i primærbehandlingen er gode data om både primær- og tilbakefallssituasjonen.

\section{ENDRINGER I MELDESYSTEMET OG NYE DATAKILDER BIDRAR TIL BEDRE MULIGHE- TER FOR REGISTRERING AV PROGNOSTISKE FAKTORER OG RESULTATER AV KREFT- BEHANDLING}

Innføringen av elektroniske pasientjournalsystemer ved sykehusene og etableringen av et nasjonalt helsenett for sikker kommunikasjon av konfidensielle helseopplysninger er i ferd med å revolusjonere kreftregistreringen. Mens opplysningene fra leger hittil er kommet på papirbaserte meldeskjemaer utfylt for hånd med legeskrift, vil vi nå motta opplysningene fra kreftmeldeskjemaer i standardisert og kvalitetssikret form via helsenettet. Vi har fått en forsmak på effekten av dette ved overføring av enkle elektroniske pasientadministrative data fra landets sykehus til Kreftregisteret med opplysninger om alle sykehusinnleggelser, diagnoser og operasjoner for kreft. Disse dataelementene har gitt stor bedring i kvaliteten på opplysningene i Kreftregisteret. Mer eksakte opplysninger som kan kvalitetssikres mot opplysninger fra andre kilder har for eksempel gjort det mulig å regne ut operasjons- mortaliteten (dødelighet innen 30 eller 60 dager etter operasjonen) (13). Fra strålebehandlingsenhetene har vi mottatt data om strålebehandling direkte fra datamaskinene som styrer strålebehandlingsmaskinene. Dette er data som er vesentlig mer korrekte enn andre data Kreftregisteret mottar, slik at kvalitetssikringen har vært relativt lite ressurskrevende. Kreftregisterets meldeskjemaer og meldesystemer er i ferd med å bli integrert i de elektroniske pasientjournalene som dels er innført, dels innføres ved landets sykehus. Kreftregisteret ønsker å være involvert i dette utviklingsarbeidet for å sikre at effektive utdrag av journalene kan gjøres elektronisk i fremtiden, både ved diagnosetidspunktet og ved tilbakefall.

Operasjonsbeskrivelsene (kirurgens rapport om det kirurgiske inngrepet) har vært en viktig kilde til informasjon om kreftbehandlingen. For endetarmskreft har det bl.a. vist seg at operasjonsbeskrivelsene gir uvurderlig informasjon om tekniske forhold som har stor betydning for behandlingsutfallet, og som ikke reflekteres $\mathrm{i}$ annen dokumentasjon.

Gjennom tidene har både epikriser (sykehusets rapport om pasientens tilstand og behandlingsforløp ved en sykehusinnleggelse) og annen skriftlig informasjon, inklusive operasjonsbeskrivelser, vært sendt til Kreftregisteret som supplement til meldeskjemaet for å bidra til å lette og fullstendiggjøre registreringen av den enkelte pasient. Det er teknisk enkelt å ta en kopi av operasjonsbeskrivelsene eller epikrisene, enda enklere å overføre elektronisk, og det medfører heller ingen tekniske problemer for Kreftregisteret å lagre beskrivelsene i datasystemet. Dette er eksempler på at ikke standardiserte datakilder er vesentlige for en korrekt og meningsfull registrering i Kreftregisteret.

Opprinnelig, da Kreftregisteret ble etablert, ble det fastsatt fra Sosialdepartementet at alle innleggelser for kreftsykdom skulle medføre at det ble innsendt melding til Kreftregisteret. Dette er først blitt gjennomført siden 1998, men data om hva som ble funnet ved innleggelser og konsultasjoner er ufullstendige. Et eget oppfølgingsskjema i elektronisk form er nødvendig å innføre for å melde alle tilbakefall av kreftsykdom, ikke bare de tilbakefall som medfører at det tas ut en vevsprøve som blir undersøkt av patolog. Kopi av patologenes uttalelse om vevsprøver som har med forstadier til eller utviklet kreft sendes alltid rutinemessig til Kreftregisteret. I forbindelse med Norsk kreftplan fikk Kreftregisteret midler til en forstudie for å se på sykehusjournalenes konsistens, kompletthet og stadfesting av diagnoseprosedyrer, behandlingstiltak og ikke minst behandlingsintensjon ved tilbakefall (14). Hva ventet man f.eks. å oppnå med de kompliserte kurene - helbredelse eller dødsutsettelse? Det vi kunne trekke ut av dette prosjektet var at en grundig systematisering og opprydning var på sin plass (14). Et hovedproblem var at dokumentasjonen i pasientjournalene ikke gav entydig svar med hensyn til om behandlingen hadde helbredelse, lindring (palliasjon) eller livsforlengelse (dødsutsettelse) som målsetting. 


\section{a) Systemer for innsamling av data om tilbakefall av kreft}

Data om tilbakefall av kreftsykdom har vært inkomplette og av variabel kvalitet, men man har på den annen side tidligere ansett det for å være en nær umulig oppgave å få til systematisk registrering av slike data. De siste års utvikling i databaseteknologien har imidlertid gitt en helt ny fleksibilitet i dataregistreringsmulighetene, noe som også gjør det mulig å registrere relativt heterogene data, data som nødvendigvis også i fremtiden vil ha ulik grad av nøyaktighet og validitet. Et menneske med andre alvorlige sykdommer ved siden av kreft vil totalvurderes annerledes med hensyn på sykdomsutredning og helbredelsespotensiale enn et som ellers er friskt. Erfaringer fra Colorectalcancerprosjektet (Kreftregisterets prosjekt for bedring av prognosen ved tykk- og endetarmskreft) tilsier imidlertid at det er mulig å systematisere og standardisere registreringen av tilbakefall slik at denne registreringen ikke byr på store problemer (15). Registreringen er relativt ressurskrevende, spesielt hvis den ikke gjøres meget planmessig og med gode systemer som maksimalt utnytter de data som finnes. For hver tumorform må det utvikles et sett av klinisk/prognostisk relevante parametre som kan karakterisere stadium, behandling og utfall av behandlingen - og metodene som er benyttet $i$ alle ledd. En del av disse parametrene er allerede tilfredsstillende utviklet $i$ form av internasjonale tumorklassifiseringssystemer. Behandlingsrelaterte parametre og mål for resultater mangler en tilsvarende omforent internasjonal standardisering for de fleste svulstformer. For endetarmskreft og til dels for tykktarmskreft, er dette arbeidet gjort. Men dette er en dynamisk prosess, som vil kreve jevnlig oppdatering og forandring av parametersettene i lys av nytilkommet kunnskap og endring av behandlingen. Det må for alle tumorformer utvikles normer for bedømmelse av radikalitet (fullstendig fjernet svulstvev) og for patologievalueringen (standard undersøkelsesmetodikk og felles terminologi).

Kreftregisteret får i dag melding om alle histologiverifiserte tilbakefall av kreft fra patologene (men dette omfatter som ovenfor nevnt ikke alle tilbakefallene). For å få utbytte av dette store materialet som nå meldes usystematisk og derfor ikke kan benyttes fullt ut i forskning eller kvalitetssikring, vil det være nødvendig med noe mer arbeidskraft i Kreftregisteret for innhenting av data fra sykehusene og for tolkning og koding av den økte mengde medisinske opplysninger. En bieffekt av dette er at man kan få innhentet dagens forsinkelse i registreringen, og få en helt annen oppdatert registrering av alle krefttilfeller i Norge, hvilket ville heve kvaliteten også på de registrerte primærdata vesentlig. På grunn av det gode grunnlagsmateriale som finnes vil grensenytten for en økt ressursinnsats være meget høy. Rekrutteringen og opplæringen av medarbeidere må skje planmessig og langsiktig. Ut over helsefaglig bakgrunn tar det minst ett år med intern opplæring å utdanne en koder/prosjektmedarbeider eller data manager.

\section{b) Samkjoring med andre registre for å oppnå kompletthet og hoy datakvalitet}

Det er vesentlig å få sikre opplysninger om dødsårsak selv om det er gått lang tid fra kreftdiagnosen til dødstidspunktet. En sterkt økende andel av dem som dør i Norge vil ha eller ha hatt en kreftdiagnose. Kopi av dødsattestene til alle pasienter med tidligere kreftdiagnose bør oversendes til Kreftregisteret i tillegg til kodene for dødsårsaker. Dette er viktig fordi behandling av visse kreftformer kan gi overdødelighet av andre årsaker enn kreft (f.eks. hjertesykdom etter visse cellegifter).

En del behandling, spesielt av non-solide kreftformer, kan i sin helhet skje poliklinisk, slik at det ikke oppstår noen sykehusutskrivelse med koder for behandling. Det bør i slike tilfeller være et vilkår for bruk av cellegifter (cytostatica) til kreftbehandlingen at pasienten er meldt til Kreftregisteret. Som kontroll kan man tenke seg at Rikstrygdeverket gir elektronisk lesbare oversikter over pasienter som har fått refusjon for innkjøp av cellegifter.

Ideelt burde det også registreres hvilke cellegifter (og eventuelt totaldose) som er gitt både ambulant og $\mathrm{i}$ sykehus for å kunne ha mulighet for å kartlegge langtidseffekten av cellegifter (senere overhyppighet av annen cancer; hjertesykdom, etc.). Det er i denne sammenheng bekymringsfullt at det nye reseptbaserte legemiddelregisteret av personvernhensyn sannsynligvis ikke vil kunne tilføre Kreftregisteret data om cellegiftbehandling. For å vurdere langtidseffekt av cellegift, er man i dag avhengig av dedikerte studier og produsentenes post-marketing surveillance, noe som ikke har et særlig langt tidsperspektiv (16).

Standardiserte databaser med enkle basisdata, supplert med data fra Kreftregisteret, vil kunne gi sykehusene god oversikt over egen virksomhet og resultater - til sammenligning med gjeldende nasjonale og internasjonale normer. Nærliggende eksempler er komplett registrering av regionale variasjoner i bruk av brystbevarende kirurgi fulgt av sammenlignende studier over overlevelse mellom behandling med tradisjonell fjerning av bryst og brystbevarende kirurgi. Tilsvarende har det vært mulig å dokumentere at valg av kirurgisk metode ved fjerning av endetarmskreft er avgjørende for tilbakefallsfrekvensen og dermed overlevelsen (12).

Elektronisk overføring av data om diagnostikk og behandling vil kunne gi on-line data til Kreftregisteret for å opprettholde et nasjonalt høykvalitets, populasjonsbasert kreftregister (17). Koding kan i stor grad skje lokalt ved validering under utfylling av elektroniske skjemaer og Kreftregisteret vil kunne sikre uniform registrering. Et slikt system med tett kontakt mellom sykehus og Kreftregisteret har ikke bare rasjonalisering som hensikt, men kvalitetssikring. Erfarin- 
ger fra Norge og andre land viser at det er meget vanskelig å få komplette data av høy kvalitet både om primærdiagnosen og om tilbakefall uten meget sterk lokal medvirkning (18). Den ekstra ressursinnsatsen som her skytes inn, vil gi en stor kvalitetsforbedring av registerdatabasen, som igjen vil gi grunnlaget for meningsfylt kvalitetssikring og -kontroll av kreftbehandlingen.

\section{c) Utenlandske erfaringer med relevans til Kreftregisterets aktivitet}

Det er publisert en lang rekke artikler med resultater fra National Cancer Data Base i USA. Man har lagt særlig vekt på Patient Care Evaluation, det vil si evaluering av hva slags behandling pasientene får, og særlig utviklingen i behandlingstilbudet over tid. Dette er en type data vi i Norge ønsker å få samlet. Som i Norge har man i USA funnet store regionale variasjoner i bl.a. behandling av brystkreft (19). Til tross for gigantiske datamengder i amerikanske databaser, har man der (blant annet på grunn av anonymisering av data) klart dårligere muligheter enn det vi har i Norge for å kartlegge behandling og behandlingsresultater, fordi vi kan få frem behandlings- og oppfølgingsdata om alle pasientene som behandles for kreft i Norge og med en relativt liten investering (20).

I The Northern Region i England har man etablert et populasjonsbasert system med kliniske data om alle krefttilfeller i en definert befolkning, men begrenset til non-solide svulster (21-23). Professor Stephen Proctor ved Royal Victoria Infirmary i Newcastle organiserte en gruppe av 28 hematologer $\mathrm{i}$ et definert geografisk område med 3,1 millioner innbyggere. Resultater av behandlingen av non-solide (hematologiske) svulster ble samlet inn for alle pasienter som ble behandlet $\mathrm{i}$ regionen og så analysert. Han kalte dette for "population adjusted clinical epidemiology (PACE)" og karakteriserte dette ytterligere som "reality based medicine" versus "evidence based medicine" $(21,24,25)$ som er basert på kontrollerte forsøk på begrensede pasientgrupper. PACE-systemet gjør at man kan komme utenom den kritikk som er reist mot randomiserte megatrials, nemlig at de bare har gyldighet for de selekterte populasjonene som er inkludert i studiene, og at man står uten kunnskap om den majoritet av pasientene som ikke er representert i kliniske studier, spesielt pasienter med flere sykdommer og eldre pasienter. PACE-systemet er nærmest opp til det system vi ønsker og kan gjennomføre i Norge på bakgrunn av tidligere erfaringer med prosjekter i Kreftregisteret.

\section{d) Det norske Kreftregisterets potensiale i klinisk retning}

Prinsippene i PACE-systemet er gjennom mange år anvendt i Kreftregisterets Colorectalcancerprosjekt, hvor alle pasienter som fikk diagnosen tykk- og endetarmskreft ble inkludert i en prospektiv studie. De mest slående resultatene fra den undersøkelsen var at ca. $30 \%$ av pasientene som ble operert med en antatt helbredende operasjon for endetarmskreft fikk tilbakefall lokalt i operasjonsområdet i bekkenet (15) og at $92 \%$ av disse døde. De beste sykehus i utlandet har færre enn 5\% lokale tilbakefall for tilsvarende pasientgrupper (26). Uten nitid registrering av opplysninger om primæroperasjonen og tilbakefallets art, ville det ikke vært mulig å få frem disse opplysningene. Som en konsekvens av Kreftregisterets funn, ble den kirurg som hadde de beste resultater av kirurgisk behandling av endetarmskreft i verden (R.J. Heald, Basingstoke, U.K.) $(26,27)$ invitert til å lære opp norske kirurger $\mathrm{i}$ den metoden (Total Mesorectal Excision, TME) han hadde utviklet. Kirurger fra hele landet er siden 1993 opplært i Norge ved deltagelse i kurs ledet av Heald. Tilsvarende ble det holdt kurs for norske patologer av den britiske patologen Phil Quirke for å få til en ensartet, strukturert undersøkelse og beskrivelse av det fjernede endetarmspreparatet. Rectumcancerregisteret $i$ Kreftregisteret har registrert data om nær 10000 pasienter som er operert for endetarmskreft siden TMEmetoden ble innført i Norge, og resultatene viser en betydelig reduksjon i lokalt tilbakefall og bedring av overlevelse (12).

Resultatene fra Colorectalcancerprosjektet og senere rectumcancerprosjektet viser klart Kreftregisterets potensiale for kvalitetssikring og som pådriver av tiltak for å bedre leveutsiktene for pasienter med kreft $(12,15,20)$.

Våre muligheter til å oppnå gode resultater i form av god kreftregistrering, resultatoppfølging og behandlingsresultater er bedre i Norge enn i alle andre land på grunn av at vi har et godt legalt grunnlag i Helseregisterloven og Kreftregisterforskriften, et fødselsnummersystem for sikker pasientidentifikasjon, en bofast befolkning med liten immigrasjon og emigrasjon, og en offentlig finansiering av kreftbehandlingen som i prinsipp sikrer hele befolkningen kreftomsorg, uten hensyn til inntekt eller bosted. På grunn av et godt lovverk og god organisering er vi også bedre stilt enn våre naboland, som tradisjonelt ellers har hatt de samme fortrinn som oss. Norges komparative fortrinn er store og kan ytterligere forbedres ved bedret innsamling av populasjonsbaserte data etter mønster av PACE. Norge burde være en attraktiv samarbeidspartner i internasjonale undersøkelser, og dette kan også bidra til at man tidlig kan få tilgang til det beste av kreftbehandling.

\section{UTNYTTELSE AV DATA I KREFTREGISTERET}

Det er en uttrykt målsetting for Kreftregisteret at de store datamengder som er innsamlet gjennom mer enn 50 år skal utnyttes maksimalt til forsknings- og kvalitetssikrings- samt planleggingsformål i kreftomsorgen. Problemer med inkomplett rapportering til Kreftregisteret har tidligere begrenset anvendelsen av data fra registeret. For bruk av data ut over insidens og overlevelse av større grupper av kreftpasienter har det $\mathrm{i}$ hvert enkelt tilfelle vært forbundet med et stort 
kvalitetssikringsarbeid å ta ut data fra Kreftregisterets database. Ved individuell gransking av meldinger har man kunnet trekke ut mer opplysninger enn det som er blitt registrert rutinemessig. Til tross for dette arbeidet har ikke data alltid hatt den kvalitet og detaljeringsgrad som vi har kunnet ønske. Disse problemene tiltok i løpet av 1990-årene på grunn av dårlige systemer for innsending av meldinger fra sykehusene og en utilstrekkelig ressurstilgang til Kreftregisteret som hindret effektive purrerutiner og dessuten ikke gjorde det mulig å registrere den økte mengden data om stadig flere krefttilfeller etterhvert som rapportene kom inn. Etter at Helseregisterloven og Kreftregisterforskriften trådte i kraft 1.1.2002 har Kreftregisteret fått en sikrere lovhjemmel for virksomheten, slik at helseforetakene har fått ansvar for rapporteringen. Dette har meget hurtig gitt resultater med en merkbar bedring av rapporteringsrutinene og dermed bedring av kompletthet og datakvalitet i Kreftregisteret. Kvalitetssikringstiltakene i Kreftregisteret har medført at utlevering av data til forsknings- og planleggingsformål vil kunne foregå med mindre innsats fra Kreftregisterets stab i det enkelte tilfelle. Dette bør kunne åpne for bedre utnyttelse av data enn det som hittil har vært mulig, også for eksterne forskere fra hele landet.

\section{KONKLUSJON}

Det finnes ingen landsomfattende sykdomsregistre i Norge som kan sammenliknes med Kreftregisteret med hensyn til erfaring med den kombinerte register-, helsetjeneste- og forskningskompetanse på sitt spesialområde. Av kompetanse-, kvalitets- og ressursgrunner er det derfor hensiktsmessig at den totale kreftregistreringen, inklusive forstadier (screening), er en del av registerets virkefelt. Kreftregisteret har et stort potensiale i populasjonsbasert, klinisk orientert forskning, som kan bidra til et bedret utfall av kreftbehandlingen. Kreftregisteret ønsker å være et kvalitetsregister for alle kreftformer. En slik satsing går ikke på bekostning av tradisjonell etiologisk forskning, men vil tvert imot styrke den ved å fremskaffe et sikrere datagrunnlag. I økende grad ønsker Kreftregisteret at aktiviteter innen registrering, kvalitetssikring og dokumentasjonsforskningen blir organisert i tverrfaglige grupper rundt den enkelte kreftform. Gruppene må være sammensatt i et nettverk mellom Kreftregisteret og eksterne fagmiljøer og enkeltpersoner. Dette temafellesskap mellom fagene og mellom et sentralt register og samarbeidspartnere landet rundt tror vi er veien å gå.

\section{REFERANSER}

1. Langner I, Blettner M, Gundestrup M, Storm H, Aspholm R, Auvinen A, et al. Cosmic radiation and cancer mortality among airline pilots: results from a European cohort study (ESCAPE). Radiat Environ Biophys 2004; 42 (4): 247-56.

2. Haldorsen T, Andersen A, Boffetta P. Smoking-adjusted incidence of lung cancer by occupation among Norwegian men. Cancer Causes Control 2004; 15 (2): 139-47.

3. Tynes T, Haldorsen T. Residential and occupational exposure to $50 \mathrm{~Hz}$ magnetic fields and hematological cancers in Norway. Cancer Causes Control 2003; 14 (8): 715-20.

4. Grimsrud TK, Berge SR, Haldorsen T, Andersen A. Exposure to different forms of nickel and risk of lung cancer. Am J Epidemiol 2002; 156 (12): 1123-32.

5. Romundstad P, Andersen A, Haldorsen T. Cancer incidence among workers in the Norwegian silicon carbide industry. Am J Epidemiol 2001; 153 (10): 978-86.

6. Robsahm TE, Tretli S, Dahlback A, Moan J. Vitamin D3 from sunlight may improve the prognosis of breast-, colon- and prostate cancer (Norway). Cancer Causes Control 2004; 15 (2): 149-58.

7. Robsahm TE, Tretli S. Cutaneous malignant melanoma in Norway: variation by region of residence before and after the age 17. Cancer Causes Control 2001; 12 (6): 569-76.

8. Tretli S, Robsahm TE. Populasjons-basert kreftregister i etiologisk forskning; illustrert ved studier basert på kobling mellom høyde- og vektdata og Kreftregisteret. Norsk Epidemiologi 2004; 14 (1): 85-90.

9. Hansen S, Norstein J, Næss Å. Cancer in Norway 2001, Kreft i Norge 2001. Kreftregisteret, Oslo 2004.

10. Harvei S, Tretli S, Langmark F. Quality of prostate cancer data in the cancer registry of Norway. Eur $J$ Cancer 1996; 32A: 104-10.

11. Tingulstad S, Halvorsen T, Norstein J, Hagen B, Skjeldestad FE. Completeness and accuracy of registration of ovarian cancer in the cancer registry of Norway. Int J Cancer 2002; 98 (6): 907-11.

12. Wibe A, Svensson E, Bjerkeset T., Carlsen E, Langmark F, Norstein J, Wiig JN, Søreide O. Rectumcancerregisteret gir kvalitetsforbedring i kreftbehandlingen. Norsk Epidemiologi 2001; 11 (2): 159-63.

13. Rostad H, Naalsund A, Jacobsen R, Strand TE, Norstein J. Årsaker til mortalitet etter reseksjon for lungekreft. Tidsskr Nor Laegeforen 2004; 124 (3): 313-5.

14. Iversen T. Utvidet registrering av kreftsykdom i Norge. Forprosjekt for registrering av tilbakefall og registrering med sikte på iverksetting av et nytt melde- og overvåkningssystem. Kreftregisteret, Oslo 1999. 
15. Norstein J, Langmark F. Results of rectal cancer treatment: A national experience. In: Søreide O, Norstein J, eds. Rectal Cancer Surgery. Optimisation. Standardisation. Documentation. Berlin: Springer-Verlag, 1997 : 17-28.

16. Abrahamsen AF. Akutt myelogen leukemi og myelodysplastisk syndrom etter cytostatikabehandling. Tidsskr Nor Laegeforen 2000; 120 (21): 2542-5.

17. Pollock A. The future of cancer registries. BMJ 1994; 309 (6958): 821-2.

18. Smith SJ, Muir KR, Wolstenholme JL, Thornhill KG, Zamorski A, Tolley K, et al. Continued inadequacies in data sources for the evaluation of cancer services. Br J Cancer 1997; 75: 131-3.

19. Osteen RT, Steele GD, Jr, Menck HR, Winchester DP. Regional differences in surgical management of breast cancer. CA Cancer J Clin 1992; 42: 39-43.

20. Langmark F. Cancer of the rectum: Epidemiology, improvement in survival and the role of a national cancer registry. In: Søreide O, Norstein J, editors. Rectal Cancer Surgery. Optimisation. Standardisation. Documentation. Berlin: Springer-Verlag, 1997: 3-16.

21. Charlton BG, Taylor PR, Proctor SJ. The PACE (population-adjusted clinical epidemiology) strategy: a new approach to multi-centred clinical research. QJM 1997; 90: 147-51.

22. Taylor PR, Reid MM, Stark AN, Bown N, Hamilton PJ, Proctor SJ. De novo acute myeloid leukaemia in patients over 55-years-old: a population-based study of incidence, treatment and outcome. Northern Region Haematology Group. Leukemia 1995; 9: 231-7.

23. Thomas MJ, Irving JA, Lennard AL, Proctor SJ, Taylor PR. Validation of the Hasford score in a demographic study in chronic granulocytic leukaemia. J Clin Pathol 2001; 54 (6): 491-3.

24. Engels EA, Spitz MR. PACE-setting research. Lancet 1997; 350: 677-8.

25. Black N. Developing high quality clinical databases. BMJ 1997; 315: 381-2.

26. MacFarlane JK, Ryall RD, Heald RJ. Mesorectal excision for rectal cancer. Lancet 1993; 341: 457-60.

27. Heald RJ, Ryall RD. Recurrence and survival after total mesorectal excision for rectal cancer. Lancet 1986; 1: 1479-82. 